\title{
POR DENTRO DA BIOGRAFIA: TRAJETÓRIA INTELECTUAL E “CAMPO LITERÁRIO" EM JÚLIA LOPES DE ALMEIDA
}

\author{
INSIDE THE BIOGRAPHY: INTELLECTUAL CAREER AND \\ “LITERARY FIELD" IN JULIA LOPES DE ALMEIDA
}

DOI: http//dx.doi.org/10.15448/2178-3748.2017.2.23227

\author{
Deivid Aparecido Costruba \\ Doutorando em História pela Unesp/Assis \\ dcostruba@yahoo.com.br
}

\begin{abstract}
RESUMO: Este texto tem como objetivo analisar a trajetória intelectual de Júlia Lopes de Almeida e suas estratégias a fim de inserir-se em uma seara literária predominantemente masculina. Para além da discussão, cabe destacar que a entrevista concedida pelo casal Júlia Lopes de Almeida e Filinto de Almeida ao cronista João do Rio fornece pistas interessantes das relações familiares da escritora carioca e, consequentemente, reforça os estudos macroestruturais no que diz respeito à biografia histórica. Esses trabalhos postulam que em uma história individual/biográfica deve-se examinar os atores como reflexos, como reveladores de uma época. Portanto, a história intelectual de Júlia Lopes de Almeida pode ser interpretada como uma história de indivíduos ou grupo de indivíduos que, neste caso específico, reivindicavam a harmonização de direitos entre homens e mulheres.
\end{abstract}

PALAVRAS-CHAVE: Sociabilidade intelectual. Mulheres escritoras. Júlia Lopes de Almeida.

\begin{abstract}
This text aims to analyze the intellectual trajectory of Júlia Lopes de Almeida and her strategies in order to enter a predominantly male literary harvest. In addition to the discussion, it is worth noting that the interview given by the couple Júlia Lopes de Almeida and Filinto de Almeida to the chronicler João do Rio provides interesting clues about the family relations of the carioca writer and consequently strengthens the macrostructural studies with regard to historical biography. These works posit that an individual/biographical history should examine the actors as reflections, as revelations about an era. Therefore, the intellectual history of Júlia Lopes de Almeida can be interpreted as a history of individuals or group of individuals who, in this particular case, claimed the harmonization of rights between men and women.
\end{abstract}

KEYWORDS: Intellectual sociability. Women writers. Júlia Lopes de Almeida.

O presente texto pretende entender a trajetória intelectual de Júlia Lopes de Almeida e suas estratégias a fim de inserir-se em uma seara literária predominantemente masculina. Cumpre lembrar que o fato de a escritora carioca ser branca, de família burguesa e ter apoio do pai e marido contribuíram, substancialmente, para o êxito na profissão. A despeito do amparo, não se pode negar o talento da escritora ora analisada, uma vez que foi agraciada, tanto em vida como após sua morte, por seus pares. 
Algumas questões reveladas na entrevista concedida pelo casal Júlia Lopes de Almeida e Filinto de Almeida a João do Rio parecem frutíferas nesta discussão ${ }^{1}$. O encontro, realizado no famoso casarão dos cônjuges no bairro de Santa Teresa, traz à luz algumas questões que possibilitam entender a trajetória intelectual da escritora, além de algumas evidências de como Júlia Lopes conseguiu se inserir nesse mundo letrado predominantemente masculino.

Do ponto de vista literário, o presente inquérito, como esclarece Brito Broca (1975), terse-ia inspirado em Jules Huret, que publicara em L'Echo de Paris, no ano de 1891, um questionário explorando a situação do naturalismo francês. Alhures, as entrevistas foram reunidas no compêndio Enquete sur l'Evolution Littéraire. João do Rio, deste modo, resolveu, à brasileira, entender o perfil da nata literária nacional na primeira década do século XX.

Para isso, o escritor entrevistou onze personagens literários e, por meio de cartas, participaram vinte e seis outros autores, compondo desta forma, um painel multifacetado da escrita da época. A importância da obra é inquestionável. Sob a moldura da bela época carioca, o compêndio, muito debatido entre os estudiosos de Letras, se situa no limiar do chamado prémodernismo e como um canal para o modernismo propriamente dito. Cumpre mostrar, ainda, a pergunta capital do questionário que tratava sobre a situação do jornalismo no Brasil. Indagouse se este seria bom ou mau para a arte literária. Na esteira destas respostas, formou-se um esboço da mentalidade literária do período.

Mas antes de concentrar-se no problema do presente texto, é preciso entender os aportes metodológicos que vão dar respaldo a esta análise. Ao se trabalhar com um indivíduo deve-se ter em mente os usos e limites da biografia histórica. Como bem esclareceu Le Goff (1990, p. 7-8), “a biografia histórica nova, sem reduzir as personagens a uma explicação sociológica, esclarece-as pelas estruturas e estuda-as através de suas funções e papéis". Para compreender os laços familiares de Júlia Lopes de Almeida, as conceitualizações de Sergio Miceli parecem mais apropriadas. O sociólogo e outros lançaram mão do termo "prosopográfico" ou "método prosopográfico", oriundo de prósopon (“caráter" ou "pessoal”) mais graphein (“escrever"), o qual figurava no campo da história antiga para designar "biografia coletiva"; contudo, o pesquisador teve a intenção de examinar "os laços familiares e das carreiras de um número considerável de pessoas numa dada sociedade, num determinado período, com vistas ao estabelecimento de inferências a respeito da estrutura social e do sistema político" (MICELI,

\footnotetext{
${ }^{1}$ Intelectual importante na virada do século XIX para o XX, João do Rio, pseudônimo de João Paulo Emílio Cristovão dos Santos Coelho Barreto, publicou inúmeras obras como o referido inquérito, além de outras que mostravam as glórias e as misérias do Brasil Republicano em plena Belle Époque.
} 
2001, p. 355). Além deste, a noção de "campo literário" do sociólogo francês parece salutar. Ao conceitualizar tal termo, também estendido a outras áreas do conhecimento, Bourdieu o traduz como sendo uma "rede de relações objetivas (de dominação ou de subordinação, de complementaridade ou de antagonismo etc.) entre posições" (BOURDIEU, 1996, p. 262). Assim, cada indivíduo detém uma posição que depende tanto de sua situação atual quanto potencial, em relação a outros indivíduos e sua distribuição de capital simbólico na estrutura do próprio campo ${ }^{2}$.

Ao considerar esta discussão, a presente reflexão usará os respectivos conceitos como um apoio para perceber como os laços familiares, a união matrimonial e intelectual do qual se nutriam Júlia Lopes e Filinto de Almeida. Bem como as relações sociais, intelectuais e as batalhas no campo literário brasileiro na virada do oitocentos, que entremearam a trajetória de Júlia Lopes.

A literata nasceu no Rio de Janeiro em 24 de setembro de 1862. Seu nome de batismo foi Júlia Valentina da Silveira Lopes e o início de sua vida literária ocorreu em 07 de dezembro de 1881. Durante quase cinquenta anos contribuiu para a literatura nacional ao escrever romances, contos, crônicas, manuais de ciências domésticas destinados às mulheres, além de contemplar um gênero incipiente no cenário da época, o livro didático.

É importante destacar que o sucesso de Júlia Lopes, no contexto literário brasileiro do início do século XX, suscita uma série de reflexões por se tratar de um fenômeno praticamente inédito. $\mathrm{O}$ fato de ser casada com Filinto de Almeida e de pertencer a uma família de intelectuais contribuiu, sem sombra de dúvida, para lhe abrir os caminhos até então interditos à mulher. $\mathrm{O}$ sucesso que alcançou naquele momento repercutiu até mesmo em Paris, onde foi alvo de uma homenagem da Societé des Gens de Lettres (XAVIER, 1994, p. III). Neste sentido, antes de refletir a respeito de seu prestígio internacional é preciso entender quem foram os progenitores de Júlia Lopes e em que contexto vieram para o Brasil.

Seus pais eram o médico Valentim José da Silveira Lopes (1830-1915) e a professora Antônia Adelina do Amaral Pereira (1830-1895), integrantes da elite portuguesa. Sua mãe era formada em canto, piano e composição pelo Conservatório de Lisboa e seu casamento ocorreu em 1849. Alguns anos depois, o casal emigrou para o Brasil (1857) e, pouco antes da partida,

\footnotetext{
${ }^{2}$ Entende-se como capital simbólico a medida do prestígio e/ou do carisma que um indivíduo possui em um determinado campo. A partir desta situação, permite-se ao indivíduo que desfrute de uma posição de proeminência frente ao campo, na qual é reforçada pelos signos distintivos que reafirmam a posse desse capital, leia-se na resistência ao campo literário, perpetrado por Júlia Lopes os seguintes distintivos: prêmios, condecorações e resenhas elogiosas de obras. Para um maior conhecimento sobre o capital de Bourdieu Cf. (BOURDIEU, 1996, 2003, 2005).
} 
presenciaram a conhecida Regeneração Portuguesa, ocorrida em $1^{\circ}$ de maio de 1851 . Esta durou dezessete anos e foi caracterizada pelo esforço de desenvolvimento econômico e de modernização de Portugal, a que se associaram pesadas medidas fiscais. Além disso, esse movimento de regeneração portuguesa foi presidido pelo Duque de Saldanha, mas o principal personagem que ficou conhecido posteriormente no imbróglio foi Antônio Maria de Fontes Pereira de Melo (1819-1887), um dos principais políticos portugueses da segunda metade do século XIX. Nas palavras de Eleonora de Luca, este período ocasionou uma época de "experimentações pedagógicas de inspiração iluminista e socialista utópica" (DE LUCA, 1999, p.492) que influenciaram os ideais dos pais de Júlia.

O casal teve sete filhos, sendo que os três primeiros nasceram em solo português e os quatro últimos no Brasil. A primeira filha do cônjuge chamava-se Adelina Amélia da Silveira Lopes (1850-1923), conhecida poetisa, contista, dramaturga, tradutora, professora pública primária e regente de coral. Casando-se, adotou o nome do marido e passou a se chamar Adelina Amélia Lopes Vieira. Formou-se professora na Escola Nacional do Rio de Janeiro e ocupou a segunda Cadeira de meninas da freguesia do Espírito Santo. Anos mais tarde, nasceu Maria José da Silveira Lopes, que se torna grande pianista com inúmeras apresentações públicas na cidade de Campinas. O último filho dos nascidos em Portugal chamava-se Valentim José da Silveira Lopes Júnior. Este enveredou pelo trabalho rural depois de assumir núpcias com Leonor Sampaio, filha de Antonio Carlos de Sampaio Peixoto, o "Sampainho", um dos pioneiros e entusiastas da modernização na região de Campinas (DE LUCA, 1999, p. 492).

Os outros filhos do casal, nascidos no Brasil, foram: Adelaide Elisa Silveira Lopes, também conhecida por seu nome de casada, Adelaide Lopes Gonçalves, cantora lírica e declamadora. Em meados de 1860, nasceu o menino Augusto Silveira Lopes, que faleceu quando contava um ano e meio de vida. Júlia Valentina da Silveira Lopes, nascida em 24 de setembro 1862, fora a penúltima filha do casal, porém conservou a condição de caçula por muitos anos. A última filha, Alice Luísa da Silveira Lopes, nasceu já na cidade de Campinas, no ano de 1871, e após o seu casamento assumiu o nome de Alice Luísa Campeão.

Júlia nasceu no casarão situado à Rua do Lavradio, localizada em frente à Rua da Relação, local onde seus pais mantinham um liceu feminino, denominado Colégio de Humanidades. Durante a residência familiar nesse domicílio, seu pai retornou à Europa para se graduar e completar a sua especialização acadêmica. Anos depois, a família mudou-se para Nova Friburgo, cidade na qual estabeleceu outro colégio. Ao voltar para o Brasil, o então doutor Valentim foi contratado para trabalhar no Hospital da Beneficência Portuguesa, localizado no 
Rio de Janeiro, em 1867. No entanto, a família não se habituou ao clima da cidade e mudou-se para Campinas, interior da província de São Paulo. Na época a cidade campineira era a capital agrícola da província e porta de entrada para o chamado Oeste Paulista.

Nos idos de 1886, a família saiu da cidade para que o doutor Valentim tratasse de sua saúde no Uruguai, entre 1876 e 1878. A escritora mudar-se-ia de Campinas aos 24 anos de idade, no momento em que ficou noiva do escritor português Filinto de Almeida (1857-1945). ${ }^{3}$ Portanto, Júlia passou boa parte de sua infância e toda a adolescência no interior, mesmo que de forma itinerante.

A escritora possuía formação essencialmente autodidata e, além disso, sua mãe e seus irmãos mais velhos também ajudaram em sua alfabetização. Na infância, todas as suas predileções foram respeitadas, entre elas, o gosto pela leitura, iniciado pelo pai com obras clássicas portuguesas. Houve, ainda, um instigante interesse em estudar piano, no qual se aperfeiçoou com o conhecido mestre do Colégio Florence, o italiano Emílio Giorgetti. Aprendeu inglês, com um professor particular, o escocês Mr. John H. Bryan. Ambos ficaram em suas lembranças, pois tiveram suma importância em sua formação espiritual e moral.

Ao que se sabe, desde pequena Júlia Lopes percebera forte inclinação às letras. Conforme demonstrou de João do Rio, há no episódio da delação da irmã:

\footnotetext{
${ }^{3}$ Filinto de Almeida (Francisco F. de A.), jornalista e poeta, nasceu no Porto, Portugal, em 4 de dezembro de 1857, e faleceu no Rio de Janeiro, RJ, em 28 de janeiro de 1945. É o fundador da Cadeira n ${ }^{\circ} .3$ da Academia Brasileira de Letras, que tem como patrono Artur de Oliveira, de quem fora amigo e foi sucedido por Roberto Simonsen. O pai faleceu pouco depois do nascimento do poeta. Entrou para o Colégio Primário, no Porto, mas não chegou a concluir os estudos. Veio para o Brasil, na companhia de parentes maternos, capitães de navios, com 10 anos, fixando-se no Rio de Janeiro a partir de 1868. Trabalhou como empregado numa papelaria e não cursou qualquer estabelecimento de ensino. Entretanto, destacou-se no jornalismo e nas letras, por esforço e tenacidade singulares. $\mathrm{Na}$ mocidade, foi ensaiador de teatro e diretor de grupos amadores. Guardou até o fim da vida o gosto pelo teatro e a mestria no dizer. Aos 19 anos, escreveu o entreato cômico Um idioma, representado em 1876, no Teatro Vaudeville. Em 1887, publicou Os mosquitos, monólogo cômico em versos e o primeiro livro de versos Lírica, composições de 1880 a 1887 . Grande amigo de Valentim Magalhães, com este colaborou no jornal literário $A$ Semana, escrevendo, de 1885 a 1887, crônicas hebdomadárias e sonetos, com o pseudônimo de Filindal. No jornalismo usou também os pseudônimos Chico Férula, A., A. Bomtempo, A. Julinto (com Júlia Lopes de Almeida), Munícipe Urbano, João da Luz, Justo Leal. P. Talma e Zé Bananal. Instaurada a República, pela lei da grande naturalização foi considerado brasileiro, pois residia no Brasil em 15 de novembro de 1889 e não se declarou dentro de seis meses, conforme previa a lei, pois não tinha o ânimo de conservar a nacionalidade de origem. Filinto de Almeida integrou-se como cidadão brasileiro, indo trabalhar como redator de A Província de São Paulo, depois transformada em $O$ Estado de S. Paulo, de 1889 a 1895 . Foi deputado na Assembleia Legislativa de S. Paulo, de 1892 a 1897. Colaborou em A América (1879-1880), da qual foi diretor, O Besouro (1878-1879), O Combate (1880), Folha Nova (1882), A Estação (1883), A Semana (1885-1887), O Mequetrefe (1886), todos do Rio de Janeiro; e no Diário de Santos (1898-1899) e A Comédia (1881), de São Paulo. Escreveu, em colaboração com a esposa, em folhetins do Jornal do Commercio, o romance A casa verde. Sua última obra é o livro Cantos e cantigas, publicado em 1915, que abrange as produções de 1887 a 1914. Na feição primitiva, era um lírico exclusivo. No segundo livro de poesias, revela progressos na forma e na inspiração. Firma-se como poeta parnasiano, expressando seus sentimentos e refletindo sobre o mundo exterior. Disponível em: http://www.academia.org.br/. Acesso: 15 jul. 2014.
} 
Pois eu em moça fazia versos. Ah! Não imagina com que encanto. Era como um prazer proibido! Sentia ao mesmo tempo a delícia de os compor e o medo de que acabassem por descobri-los. Fechava-me no quarto, bem fechada, abria a secretária, estendia pela alvura de papel uma porção de rimas (...) De repente, um susto. Alguém batia a porta. E eu, com a voz embargada, dando voltas à chave da secretária: já vai! Já vai! (RIO, 1994, p. 28-37).

Júlia Lopes, quando inquirida por seu entrevistador, relatou como foram seus primeiros versos no mundo das letras. Segundo suas palavras "a mim sempre me parecia que se viessem a saber desses versos em casa, o mundo viria abaixo". O dia em que fora pega por sua irmã a rabiscar uma composição de uma história foi um grande momento em sua vida. Ao contrário do que imaginara, Dr. Valentim não ficaria zangado com o ocorrido:

Um dia, porém eu estava muito entretida na composição de uma história, uma história em verso, com descrições e diálogos, quando senti por trás de mim uma voz alegre: - Peguei-te, menina! Estremeci, pus as duas mãos em cima do papel, num arranco de defesa, mas não me foi possível. Minha irmã, adejando triunfalmente a folha e rindo a perder, bradava: - Então a menina faz versos? Vou mostrá-los ao papá!... Na sala, o papá lia gravemente o Jornal do Comércio... Meu pai, muito sério, descansou o Jornal. Ah! Deus do céu, que emoção a minha! Tinha uma grande vontade de chorar, de pedir perdão, de dizer que nunca mais faria essas coisas feias, e ao mesmo tempo um vago desejo que o pai sorrisse e achasse bom. Ele, entretanto, severamente lia. Na sua face calma não havia traço de cólera ou de aprovação. Leu, tornou a ler. A folha branca crescia nas suas mãos... Então o que achas? O pai entregou os versos, pegou de novo o Jornal, sem uma palavra, e a casa voltou à quietude normal... (RIO, 1994, p. 28-37).

Apesar do silêncio sepulcral, foi um bom momento para Dr. Valentim descobrir os escritos secretos de Júlia. No dia seguinte, ambos foram ao teatro prestigiar a atriz italiana Gemma Cuniberti (1872-1940). Ao sair do espetáculo Dr. Valentim perguntou:

Que achas da Gemma? - Um grande talento imagina! O Castro pediu-me um artigo a respeito. Ando tão ocupado agora! Mas o homem insistiu, filha, insistiu tanto que não houve remédio. Disse-lhe: não faço eu, mas faz a Júlia... (RIO, 1994, p. 28-37).

Neste momento da entrevista a escritora lembrava sua iniciação na Gazeta de Campinas. Ao entregar a tarefa à filha, Dr. Valentim permaneceu impassível como se tivesse dito coisas naturais para uma moça de dezenove anos. "Mas depois do almoço, antes de sair, o pai lembrou-me como se lembra a um escritor... era como se o mundo se transformasse". (RIO, 1994, p. 28-37).

Cabe frisar que Castro, amigo de Dr. Valentim, não havia pedido a confecção do artigo. "Só mais tarde, muito mais tarde, é que vim saber a doce invenção do meu pai. O Castro nunca 
exigira um artigo a respeito da Gemma...” (RIO, 1994, p. 28-37). Nestas passagens é fácil perceber que, além de não impedir as predileções literárias de Júlia Lopes, seu pai proporcionou a esta sua inserção no mundo letrado dominado por homens. Diferentemente do usual à época, momento em que proibiam a leitura às filhas ou escolhiam livros apropriados para lerem, Dr. Valentim despertou o gosto da escrita e leitura em Júlia.

Ainda cabe salientar que muitos autores e/ou livros que Júlia Lopes citou ou a que fez referência durante sua vida literária eram benquistos entre médicos. Sendo assim, as ideias de alguns escritores estrangeiros tiveram grande difusão no campo da medicina brasileira nas últimas décadas do século XIX. A leitura de Herbert Spencer ${ }^{4}$ foi, por exemplo, largamente procurada por alguns, inclusive o pai de Júlia Lopes, que era médico. Desse modo, não foi mera coincidência que a escritora, como outras literatas brasileiras do período, fizessem clara alusão a Spencer. Pode-se supor que Júlia Lopes utilizou-se da biblioteca de seu pai para suas leituras, daí surgiram as influências que marcaram seus escritos. Em alguns de seus textos, também defendeu os direitos da mulher e as incentivou à prática de exercícios físicos e aos cuidados com a saúde do corpo. A sugestão era uma clara referência ao livro de Spencer publicado em 1863, Education: Intelectual, Moral and Physical, no qual ele dissertava sobre a ignorância da “jovem mãe", ao creditar a falta de conhecimentos ao caráter inútil do tipo de educação nos colégios femininos.

Assim, a partir do plano executado por seu pai, estreou em oito de dezembro de $1881,{ }^{5}$ na Gazeta de Campinas, na época dirigida pelo poeta gaúcho Carlos Ferreira. Seu conteúdo relatava a apresentação no Teatro São Carlos de Gemma Cuniberti (1872-1940). A carta, como

\footnotetext{
${ }^{4}$ Herbert Spencer nasceu em Derby, Inglaterra, em 1820, e desde a adolescência mostrou ter uma personalidade anticonformista. Aos 13 anos, tentou fugir da educação oferecida por um tio que era pastor protestante, mas teve que voltar à escola, onde se manteve até os 16. Depois disso, deu continuidade sozinho a sua formação, com leituras que se concentraram acima de tudo em ciências. Queria ser inventor e acabou, pelo conhecimento que adquiriu sozinho, trabalhando como engenheiro ferroviário. Paralelamente, começou a publicar artigos em que já defendia ideias liberais, argumentando que a ação dos governos não deveria ir além de garantir os direitos naturais dos cidadãos. Em 1848, tornou-se subeditor da revista The Economist, na qual trabalhou até 1853. Manteve-se ativo até sua morte, em 1903. Spencer relacionou-se com os principais intelectuais ingleses de seu tempo e manteve um romance com a escritora George Eliot (pseudônimo de Marian Evans). Sua obra teve enorme repercussão dentro e fora da Grã-Bretanha. Algumas das principais obras de Spencer foram: Filosofia Sintética (que publicou em série, com pagamento de assinatura antecipada por seus admiradores), O Homem contra o Estado, Educação Intelectual, Moral e Física e Autobiografia. Cf. FERRARI, Marcio. Herbert Spencer - O ideólogo da luta pela vida. Revista Nova Escola. São Paulo, out. de 2008. Disponível em: http://revistaescola.abril.com.br/historia/pratica-pedagogica/ideologo-luta-pela-vida-423128.shtml. Acesso em: 25 jul. 2014.

5 Para que não haja confusão, as datas que, a partir daqui constam no presente trabalho, referem-se à data de publicação dos contos, romances, peças, atos etc. da escritora. Quando houver necessidade, mencionar-se-á que tal trabalho foi publicado em uma data posterior ao que foi escrito.
} 
mencionou Júlia, intitulada com o nome da atriz italiana, merece uma versão integral de seu conteúdo, pois mostrou a escritora num grande assombro e receio de seu debute:

\section{Sr. Redator.}

Venho trêmula pedir-lhe o braço, para que me apresento em público a atraente, a divinal criança, a encantadora Gemma! Com sua apresentação, fico certa do melhor acolhimento.

Desculpe-me para com ela e para com todos que me lerem do mal tecido da linguagem com que escrevi essas linhas que lhe envio, abusando, sem dúvida, da concessão de um cantinho no seu jornal.

Quero que me dispense toda a sua indulgência, que sei ser excessiva, e me alcance o favor de seus leitores, dizendo-lhes que o influxo do anjo que ora me leva a imprensa, não se repetirá talvez em toda uma longa vida.

$\mathrm{O}$ entusiasmo tolhe-nos ordinariamente a palavra, e eu entusiasmada estou a pedir-lhe que publique palavras minhas na Gazeta! Palavras minhas! Minhas! ... Oh! Meu Deus! Estou escrevendo e acrescentando mentalmente a cada frase uma linha de pontos de exclamação! Mas que pontos! Mas que linhas! Pontos enormes! Linhas sem fim!...

Agradecendo a benevolência com que me leva a presença do gentil portento, assunto desta carta, peço-lhe que beije por mim as faces rosadas da esplêndida artista.

Quando eu era pequena sonhava, como todas as crianças com umas brancas e luminosas fadas, que viviam vestidas de nuvens e coroadas d'estrelas, e espera ver essas divinas criaturinhas com uma ansiedade louca! Mas ... o tempo passou, e, inexorável, foi desfazendo a proporção que eu ia caminhando na idade, aquelas imagens transparentes.

Vi sem lágrimas dissolver a minha fantasia. As ilusões que temos mais esplendentes são as da infância, e nós as desfolhamos quase com alegria como se fossem rosas, entregando uma por uma as pétalas ao vento, sentindo prazer em vê-las borboletear no espaço.

Só em sonhos pode existir o que é sobrenatural, e a imaginação infantil cria prodígios de absurdas dimensões.

Eu tinha me esquecido já há muito tempo das varinhas de condão daquelas fadas gentis dos meus sonhos, quando entrei uma noite no teatro.

Esperei impaciente que principiasse o espetáculo. Levantou-se o pano e o meu olhar fixou-se ávido n'um vultozinho encantador.

Ouvi-lhe com graça a mais natural repetir uma lição de geometria e de gramática enquanto olhava de soslaio para o tirano o tio!

Desde então senti-me presa a essa imagem ideal e iluminadora e para logo surgiu-me na memória a visão de outrora, e murmurei de mim para mim: esta vale ainda mais! A voz da talentosa e ciumenta bambina tinha o tremular das estrelas que d'antes engrinaldavam as gentis criações da minha fantasia!

Oh! Minha loira e adorável Gemma, deixa que eu te fale por um momento, já que não poderei tornar a ouvir-te.

Falar contigo, é já quase uma alegria! Seria muito mais completa se te tivesse sentada em meus joelhos e pudesse mergulhar o meu olhar em teus olhos, nesse mar azul, límpido transparente e profundo! Sim seria verdadeiramente feliz se pudesse ouvir uma e muitas vezes de teus lábios essas palavras, dulcíssimas e cristalinas, se pudesse ver de bem perto mais vezes esses acionados ligeiros, graciosos, inimitáveis, como o adejar das andorinhas.

Fica-me uma consolação: se te não dou um beijo de despedida já te dei muitos, já te abracei comovida e vaidosa por poder assim manifestar-te o meu entusiasmo. 
As palavras que te mando com a singeleza sincera de quem diz o que sente e que confirmam o que o que te disse a poucos dias una povera giovenetta ${ }^{6}$, que nunca escreveu para o público, mas que o toma por testemunha de que te admira e que saudosa te vê partir, devem servir para lembrar-te que n'um canto d'uma província do Brasil deixas gravada a tua imagem n'um coração como no interior das catedrais da tua esplendorosa Itália deixaram os grandes gênios esculturados para todo o sempre os anjos do Senhor!

Vai, gênio portentoso; vai com as benções de Deus e com os votos que a mais humilde de tuas admiradoras faz pela tua felicidade.

Seguirei o teu conselho: quando encontrar, como tantas vezes me tem acontecido, esses pequenos mendigos, pálidos e tristes, desgraçadinhos que arrancam das plangentes cordas de suas desafinadas harpas e violinos, dolorosos sons com que se divertem crianças felizes aconchegadas aos seios maternos e aos mimos do lar e da família, descansa que terei para eles essas palavras de conforto que pedem as lágrimas da meiga Bambina abandonata, da gentil e admirável Roseta.

Esta página arrancada as minhas impressões, que lutei para arremessar assim ao Niágara das manifestações de entusiasmo, que te cercam em flores, em sons, em luzes, diz pouco.

Nada mais há que possa juntar ao teu nome, que não tenha sido dito por outros que melhor o podem; tem porém a certeza, oh! Minha branca fada, que só pelo teu condão pude eu sair a público manifestando o que desejo para ti: uma carreira interrompida de triunfos, e de glórias dignas só da prodigiosa, da encantadora Gemma.

Ficam-me lágrimas nos olhos ao murmurar-te ao ouvido estas palavras:- Non te vedro mai piú? ${ }^{7}$

Júlia Lopes de Almeida (GAZETA DE CAMPINAS, 07 dez. 1881, p. 7) ${ }^{8}$

A partir da missiva transcrita acima, percebe-se que a escritora, definitivamente, escrevera o primeiro texto jornalístico. Contudo, escrever em um jornal de circulação considerável para a época era motivo para tremerem-lhe os braços. Júlia Lopes teceu elogios à atriz italiana do início ao fim do artigo. Destaca-se a maneira em que a literata tratou a si própria considerando-se una povera giovenetta que nunca escrevera para o público, e o tom intimista desta expressão tinha por finalidade mostrar que Júlia dominava, ainda que pouco, o idioma italiano.

Após esta carta, a carioca produziu cerca de setenta textos que foram publicados nos jornais Gazeta de Campinas, Correio de Campinas e Diário de Campinas. Destes faziam parte contos, crônicas, resenhas, traduções do francês, iluminuras ou fragmentos de prosa poética e alguns textos que foram inseridos posteriormente no manual de ciências domésticas denominado Livro das noivas (1896). O único gênero para o qual Júlia não demonstrava

\footnotetext{
${ }^{6}$ Termo do italiano, que significa "uma pobre jovenzinha".

7 Tradução do italiano: "Não te verei nunca mais?".

${ }^{8}$ Encontra-se ilegível e borrado em algumas partes. Preferiu-se manter a forma do texto original, por ser o texto do gênero carta. Considerou-se esteticamente desaconselhável reduzi-lo à formatação normativa.
} 
inclinação era a poesia ${ }^{9}$, diferente da irmã, Adelina Lopes, que se consagrara poetisa na mesma época. Sua fama chegou até às terras portuguesas e sua consagração deu-se com as publicações da coletânea Margaritas (1878) e o poemeto Pombal (1882).

No ano de 1887, Júlia casou-se com Filinto de Almeida, em Portugal, no dia 28 de novembro. O noivo, embora de origem lusitana, era radicado no Brasil, e aqui passou a maior parte de sua vida. Notabilizou-se como jornalista e poeta, e foi um dos fundadores da Academia Brasileira de Letras, graças aos laços de amizade que o aproximavam da maior parte da intelectualidade da capital federal do final do século. É importante notar que Júlia produziu vasta obra literária, como outros intelectuais que também despontaram nos finais do século XIX. Ao se propor a escrever obras destinadas à moral das crianças e à instrução feminina, referendou sua inserção no mundo letrado, pois trabalhos como Livro das noivas (1896) e Livro das Donas e Donzelas (1906) se igualaram às propostas de "progresso" formuladas pelos médicos e higienistas da época, que afirmavam que a mãe deveria ser a responsável em educar os filhos e filhas. Ao ensiná-los, iniciaria um processo de higienização no âmbito familiar e, assim, a higiene se propagaria da esfera privada para a pública. Neste sentido, somado a este fato, mais a excelente vendagem destes manuais, Júlia Lopes de Almeida conseguiu se destacar no universo literário masculino e tornou-se uma escritora reconhecida por seus pares, tanto por legitimar um padrão burguês de conduta, quanto por corroborar com o projeto de saneamento veiculado à cidade do Rio de Janeiro na virada dos oitocentos.

É curioso notar, ao retomar Miceli, que tais "laços familiares e de carreira" (MICELI, 2001, p. 355), observados na trajetória individual de Júlia Lopes de Almeida até aqui exposta, proporcionaram uma relativa valorização de um tipo de escrita que Júlia Lopes foi tributária, em outras palavras, textos que compactuavam com os ideais de progresso propagandeados por intelectuais homens. Desta forma, como pontuou Bourdieu, a "rede de relações objetivas", que também pode ser traduzida como dominação, subordinação, complementaridade e/ou antagonismo, podem ser visualizadas na estreita subordinação dos escritos de Júlia Lopes aos textos de literatos do sexo oposto. Cabe destacar, no entanto, que a batalha para a inserção no campo literário se deu aos poucos. A partir desse trânsito, o que se verificou foi o crescimento do prestígio e/ou do carisma da escritora em questão.

\footnotetext{
${ }^{9}$ No livro Histórias da Nossa Terra (1907), há fragmentos de poesia, que não possuem, no entanto, substância em relação aos outros gêneros literários que Júlia escrevia. Estes fragmentos são considerados fragmentos de poesia, por isso não podem ser analisados como um compêndio poético.
} 
Talvez seja esta uma das explicações para o caso de Filinto de Almeida. Fundador da cadeira $n^{\circ} 03$ da Academia Brasileira de Letras carregara por toda a vida a alcunha de "acadêmico consorte", perante os seus colegas literatos. Quando indagado por João do Rio sobre a possibilidade de a escritora ser considerada "o primeiro romancista brasileiro", Filinto respondeu: “- Pois não é? Nunca disse isso a ninguém, mas há muito que o penso. Não era eu quem deveria estar na Academia, era ela" (RIO, 1994, p. 28-37).

O literato maranhense Humberto de Campos tinha a mesma opinião do marido de Júlia ao dizer que a escritora merecia muitos elogios por "ela própria, pela nacionalidade, pelo talento, mais acadêmico que o marido." (apud MACHADO NETO, 1973, p. 193). Pode-se supor que a intelectualidade acreditava que Júlia possuía uma maior aptidão para as letras do que Filinto. Mas o fato de ser mulher não lhe permitiu que seu talento fosse consagrado em instituições ainda de cunho patriarcal como a Academia Brasileira de Letras. Com isso, os chamados "falsos prestígios", ${ }^{10}$ aos quais se referiu Machado Neto, encaixam-se perfeitamente nesse caso.

Nesta senda, a alcunha de "imortal por acaso" foi associada a Filinto de Almeida. Já discutido pela historiografia sobre o assunto, no ano de 1897, quando a Academia foi fundada, alguns intelectuais queriam eleger a escritora Júlia Lopes de Almeida para uma das cadeiras, contudo, o ingresso de mulheres não era permitido ${ }^{11}$. A intelectualidade resolvera então, numa espécie de homenagem à ficcionista, eleger seu marido.

Eis que surge então a questão para os pesquisadores que têm como tema a produção da escritora: Filinto seria intelectual que viveu à sombra de Júlia Lopes ou era um literato digno de destaque em tal campo? Não se pretende aqui resolver esse impasse, mas pode-se perceber o grau de complexidade do campo literário em que Julia estava estabelecida. É fundamental frisar a importância dos bens simbólicos na estrutura social, como bem explicam dois estudiosos da obra bourdieusiana, Maria Alice e Claudio Nogueira. Segundo os autores, "Bourdieu argumenta que a estrutura presente nos sistemas simbólicos e que orienta (estrutura) as ações dos agentes sociais reproduz, em novos termos, as principais diferenciações e hierarquias presentes na sociedade, ou seja, as estruturas de poder e dominação social" (NOGUEIRA e

\footnotetext{
${ }^{10}$ No capítulo denominado "Falsos Prestígios" discutiu-se sobre os vários escritores que foram laureados por seus pares, não pela sua qualidade e competência, mas por relações de apadrinhamento. Cf. (MACHADO NETO, 1973, p. 189).

${ }^{11}$ Esta proibição só foi quebrada em 1977, ano em que a escritora Rachel de Queirós conseguiu tal proeza. Cf. o trabalho de doutoramento de Michele Asmar Fanini intitulado Fardos e fardões: mulheres na Academia Brasileira de Letras (1897-2003).
} 
NOGUEIRA, p. 34, 2004). Leia-se, ainda aqui, a hierarquia abissal entre homens e mulheres na sociedade do período.

De uma maneira mais específica, sem levar em consideração a forte submissão sofrida por inúmeras moças, o caso singular de Júlia Lopes, ao se entender a relação de mútuo respeito e admiração nutridos pelo casal Almeida, foi um dos fatores que respaldaram a carreira da escritora no mundo letrado.

No entanto, antes de empenhar-se na tarefa de elencar os fatores que contribuíram para o triunfo da escritora, cumpre frisar que a soma da narração de uma vida mais os "movimentos encadeados e uma intriga codificada por fatos reais, interpretados" (DEL PRIORE, 2009, p. 11) são partes de uma escrita biográfica. O historiador-biógrafo deve, portanto, contar a história real de uma vida, o que põe o historiador no centro da problemática da narrativa ou de seu retorno (AVELAR, 2010). Com efeito, como assinala Le Goff, “a biografia histórica deve se fazer, ao menos em certo grau, relato, narração de uma vida, ela se articula em torno de certos acontecimentos individuais e coletivos - uma biografia não événementielle não tem sentido" (LE GOFF, 1990).

Volta-se à relação familiar Julia Lopes de Almeida e Filinto de Almeida. Alguns pontos podem ser elencados para perceber esta relação. Primeiro, cabe destacar que João do Rio não pretendeu fazer uma entrevista separada, a sós com Filinto de Almeida ou com Júlia Lopes, mas sim com ambos, e a união dos dois é reforçada com o título que nomeia o capítulo, "Um lar de artistas".

Outro fato importante, o próprio entrevistador ressalta a admiração mútua do casal. Nas palavras de Rio:

Esse sentimento de mútua admiração é um dos encantos daquele lar. Filinto esquece os seus versos e pensa nos romances da esposa. Leva-a a certos trechos da cidade para observar os meios onde se desenvolverão as cenas futuras, é o seu primeiro leitor, ajuda-a com um respeito forte e másculo. D. Júlia ama os versos do esposo, quer que ele continue escrever, coordena o volume prestes a entrar no prelo. E ambos, nessa serena amizade, feita de amor e de respeito, envolvem os filhos numa suave atmosfera de bondade (RIO, 1994, p. 28-37).

Filinto tornara-se o primeiro leitor de Júlia enquanto esta coordenava o volume que entraria no prelo. A admiração não é evidenciada apenas na organização das obras em vias de serem publicadas, mas também nas dedicatórias presentes em algumas dessas como no conhecido compêndio Livro das Noivas (1896). A dedicatória do livro, intitulada "A Meu Marido", é adornada com um de seus poemas, Lyrica, que ilustra o respeito da escritora. $\mathrm{Na}$ 
epígrafe, lê-se: "As nossas almas já se uniram de tal sorte, que nem a própria morte no-las desunirá" (ALMEIDA, 1945, p. 143). Abaixo, o manual é prefaciado por uma carta aberta a Filinto de Almeida:

\begin{abstract}
Meu Filinto,
Lês na minh'alma como em um livro aberto. Não tenho pensamento que te não comunique, desejo ou sonho que te não exprima. Ninguém, pois, melhor que tu, conhecerá a sinceridade d'estas paginas singelas, onde de vez em quando os nossos filhos aparecem, e que te entrego, certa de que serão queridas ao teu coração.

Não te dou um livro literário, mas dou te um livro sentido, o que segredei todas as minhas alegrias e tristezas.

$\mathrm{Tu}$, que tens, com igual carinho e bom conselho, comparticipado de uma e de outras, acolhe-o bem, que vai nele todo amor da tua. Julia. (ALMEIDA, 1905, p. 7).
\end{abstract}

Filinto de Almeida, quando publicou Lyrica (1897), no mesmo ano em que se casaram, dedicou sua coletânea poética à noiva e às pessoas do círculo familiar dela. Já em 1915, veio a público Cantos e cantigas, segunda coletânea do poeta, onde também dedicou poemas à esposa. Cumpre lembrar que o escritor, quatro anos após a morte de sua mulher, escreveu Dona Júlia. Tratava-se de uma obra em que o autor narra as três fases de sua vida conjugal: como noivo, casado e viúvo. Destaca-se ainda o poema 24 de setembro, que fazia referência ao dia do aniversário da escritora:

\author{
Há três quartos de século nascias \\ Nesta antiga cidade colonial. \\ E eu, tão longe de ti, em Portugal, \\ Tinha cinco anos menos alguns dias. \\ Quem me diria então, que tu serias \\ Da minha vida o portentoso ideal \\ E que por meu amor, amor total, \\ Mais tarde, a todo bem renunciarias! \\ Há cinquenta anos esse amor veemente \\ As nossas vidas nos uniu por fim, \\ E ficávamos os dois sendo um somente. \\ A Primavera me mostrou assim \\ Que, no seu quarto dia, expressamente \\ Os deuses te criaram para mim. (ALMEIDA, 1938, p. 101).
}

Ainda no que diz respeito à convivência do casal, o ambiente tranquilo do lar é notado, em certos momentos da entrevista, quando os filhos do casal aparecem curiosos para ver o visitante. "Uma criança loira, de uma beleza de narciso, aparece à porta. É Margarida. As suas longas mãos no ar, chamando a mãe, são tão finas e rosadas que recordam as pétalas dos crisântemos" (RIO, 1994, p. 28-37). Em meio às conversas descontraídas, Júlia percebe que faz 
tempo que não vê o filho, levanta-se e diz: "Vou ver o Albano, coitadinho... Já não o vejo há muito tempo". Outra filha apareceu na sala e João do Rio acrescentou: "Mas aparece a Lúcia, a outra filha, uma beleza brasileira, morena, redondinha acariciadora". Após cobri-la de beijos, Filinto confidenciou: “-Sabes como eu a chamo? Sinhá Midobi. Ai! A minha filha! E faz versos. Esta casa está perdida, fazem todos versos, são todos poetas, o menos poeta sou eu...” (RIO, 1994, p. 28-37). Pode-se notar que além do apoio mútuo do casal, ambos também apoiavam a inserção de seus filhos no mundo das letras. Assim como Júlia fora incentivada por seu pai, também influenciava sua prole. Prova disso está na trajetória intelectual de Afonso Lopes de Almeida, que seguiu poeta assim como o pai. Onze anos após a morte de Júlia Lopes de Almeida, Afonso Lopes escreveu o livro intitulado Mãi. Vale frisar que o escritor, tal como Filinto, dividiu a obra em duas fases, antes e depois da morte da mãe. Dentre as composições merece destaque o poema "A nossa casa" que, tudo indica, deveria ser o mesmo lugar da entrevista de João do Rio:

Meu lar é um ninho a beira da montanha,

Suspenso sobre as casas da cidade;

Se o sol, logo ao nascer, o aquece, e o banha,

Manda-lhe a derradeira claridade.

Foi feito de pedra, com tamanha

Solicitude e força de vontade,

Que ao vê-lo pronto ainda a nossa alma estranha

Ver a imaginação feita verdade!

Fica no monte, a meia altura, tanta

Que não seja difícil lá chegar.

No plaino, a vida urbana estua e canta

E ao vê-lo, eu julgo-o assim como um altar

$\mathrm{Na}$ aba da serra, e, em baixo, aos pés da Santa,

A cidade de joelhos a rezar... (ALMEIDA, 1945, p. 19-20).

Outro ponto a ser destacado é o fato do reconhecimento da parte de Filinto de que era para Júlia pertencer à Academia Brasileira de Letras e não ele. No momento em que a esposa se retirou da sala e foi procurar o filho Albano, Filinto confidenciou para o entrevistador a possibilidade de a esposa figurar no rol de membros da Academia.

Não se pode deixar de citar a posição da escritora em relação a um assunto polêmico: quando questionada sobre o feminismo, pode-se supor que, pela presença do marido e por respeitá-lo, se absteve da discussão, ou ainda, como percebeu João do Rio, houve a impressão de certa ironia em sua resposta: ${ }^{12}$

\footnotetext{
${ }^{12}$ Apesar de Jeffrey Needell afirmar que a atitude de Júlia "em relação ao feminismo é implicitamente negativa na entrevista", pode-se pensar que quando tergiversou sobre o assunto, foi por respeito ao marido. Contudo, o "brilho nos olhos de uma vaga ironia" observados por João do Rio, aguça a reflexão histórica e ao debate. Neste sentido,
} 
- E o feminismo, que pensa do feminismo?

Parece-me ver nos olhos de D. Júlia um brilho de vaga ironia.

- Sim, com efeito, há algumas senhoras que pensam nisso. No Brasil o movimento não é contudo grande. Acabo de receber um convite de Júlia Cortines para colaborar numa revista dedicada às mulheres. Descanse! Há uma seção de modas, é uma revista no gênero da Femina... (RIO, 1994, p. 28$37)$.

Vale observar que a impressão de certa ironia observada por João do Rio dá diversas pistas ao leitor, uma vez que se tenha um conhecimento dos escritos e da vida familiar de Júlia Lopes. A questão direciona-se, pois, ao porque da hesitação na resposta, uma vez que o feminismo é um assunto caro em seus escritos ${ }^{13}$. Tendo como fito a práxis feminista em Júlia Lopes e a tentativa do historiador-biógrafo em tentar escrever uma história linear, coloca-se, pois, diante da crítica à "ilusão biográfica”, como já bem esclarecida por Bourdieu. O sociólogo abalroa-se na conjectura "de que a vida constitui um todo, um conjunto coerente e orientado, que pode e deve ser apreendido como expressão unitária de uma 'intenção' subjetiva e objetiva, de um projeto" (BOURDIEU, 1996, p. 184). Desta forma, a despeito do historiador ludibriarse na tentativa de uma escrita de narrativa de vida sob a forma linear, sem hesitações, interrupções, espaçamentos, desconstruções; parece ser difícil construir uma trajetória de vida contínua, sem rupturas e sinuosidades.

Por último, apesar de a crítica eleger o romance A Falência (1901) como obra máxima da autora, e mesmo o livro A Viúva Simões (1897) ser comparado a O primo Basílio (1878), de Eça de Queirós, ao ser inquirida sobre qual dos seus livros preferia, Júlia elegeu uma de suas obras escrita a quatro mãos:

- Ainda uma pergunta: dos seus livros qual prefere?

- Vai ficar admirado.

- É A Falência?

\begin{abstract}
é importante destacar que anos antes da entrevista Júlia Lopes já escrevera livros de temática feminista como $A$ Viúva Simões (1897), protagonizado por Ernestina, viúva do comendador Simões que se apaixonou pelo namorado da filha. Em 1899 é publicado o romance Memórias de Marta, cujas protagonistas são duas Martas, mãe e filha, sendo que a história se destina a narrar a vida num cortiço. Já em 1901 veio a público A falência, romance ambientado no cenário do encilhamento, a personagem Camila se destaca por trair o marido com o médico da família. Isto sem mencionar o compêndio Eles e Elas, publicado e escrito após a entrevista, mas que aludiu a um momento de inversão dos papéis masculino/feminino e/ou "homem/público" e "mulher/privado" dissonantes com as propostas conservadoras de Auguste Comte, que atestou o conceito de esferas separadas de atuação para os homens e mulheres (permitindo-se a eles agir no espaço público, enquanto elas deviam se limitar ao círculo privado) e estabelecendo uma suposta "divisão natural" entre atributos masculinos e femininos. Em resumo, são obras que refutam a afirmação de Needell e engendram um debate sobre o motivo da abstenção de sua resposta. Sobre as ideias de Comte Cf. (DE LUCA, Leonora. p.180, 2004). Sobre a afirmação de Needell Cf. nota número 121 (NEEDELL, 1993, p. 334).

${ }^{13}$ Atualmente as pesquisas do autor deste texto direcionam-se a entender a trajetória feminista da escritora Júlia Lopes de Almeida.
\end{abstract}

Oficina do Historiador, Porto Alegre, EDIPUCRS, v. 10, n. 2, jul./dez. 2017, 
- Não.

- O primeiro?

- Não, é A Casa Verde, porque foi escrito de colaboração com meu marido. A Casa Verde lembra-me uma porção de momentos felizes... (RIO, 1994, p. 28$37)$.

Ao dar preferência ao livro A Casa Verde (1898-1899), a literata se isenta da glória literária que alguns críticos lhe atribuíram, ao mesmo tempo em que concede a Filinto de Almeida o mesmo congraçamento de tal prestígio, já que enfatiza os momentos felizes que passaram juntos na confecção da obra. O marido, ao comentar sobre o canevas, ou seja, o esboço da obra, destacou: "Imagina eu fazendo romances! Era porque ela queria. Também só me sentava à mesa depois que me dizia: tem que fazer um capítulo hoje com estes personagens, dando-lhe este desenvolvimento" (RIO, 1994, p. 28-37). Observa-se um mútuo respeito ao perceber que da mesma maneira que Júlia Lopes se lembrou de seu marido na escolha da melhor obra, este se redimiu e creditou à esposa a coordenação do compêndio.

É curioso também notar a forma pseudônima como o casal assinava alguns textos: “A. Julinto". Diante deste fato, cabe relatar que a sincronia dos cônjuges no âmbito intelectual também serviu de pano de fundo para a instrução dos filhos e netos. $\mathrm{O}$ casal Almeida teve seis filhos, três meninos e três meninas. O primogênito do casal foi Afonso Lopes de Almeida (1888-1953), que além de escrever poemas, seguiu a carreira de diplomata. Após o nascimento de seu primeiro filho, Júlia perdeu os bebês Adriano e Valentina. No ano de 1894, a escritora deu à luz a Albano Lopes de Almeida (1894-1990), que foi poeta e artista plástico. Ao fim do século XIX, nasceu Margarida Lopes de Almeida (1897-?), que foi declamadora e escultora. Desde pequena percebia-se nela um talento nato, pois se apresentava em público com grande desenvoltura, recitava poemas em conferências e participava de vários saraus literários, nas dependências do salão do Jornal do Commercio. Margarida estudou na Escola de Belas Artes e ganhou um concurso de escultura em 1922. Este feito fez com que obtivesse a Grande Medalha de Ouro e, por méritos, uma viagem a Paris. Já Lúcia Lopes de Almeida (1899-?), também nascida no final do oitocentos foi a última filha do casal e caçula dos quatros irmãos e atuou como poetisa e prosadora. Percebe-se que entre os filhos de Júlia, a afinidade com a cultura e com as artes sempre nortearam suas vidas. Isso se evidenciou nas gerações seguintes, pois a neta do casal, Fernanda Lopes de Almeida (1920-) ${ }^{14}$, se destacou ao escrever obras de cunho infantil, ao ter uma extensa produção como escritora.

\footnotetext{
${ }^{14}$ Fernanda Lopes de Almeida foi um dos nomes mais expressivos na área da literatura infantil brasileira a partir da década de 1970. Teve vários best-sellers publicados em São Paulo pelas Edições Melhoramentos e pela Editora
} 
Por fim, ao recuperar as palavras de Le Goff (1990, p. 7-8), o relato biográfico, grosso modo, pode esclarecer as funções e papeis dos indivíduos. Júlia Lopes de Almeida estava inserida em um contexto oligárquico, cujos núcleos familiares diferenciavam-se dos tradicionais. Famílias de muitas posses que produziam filhos eruditos. É neste diapasão que surgiram as principais vozes femininas contrárias à opressão da mulher. Como esclareceu Celi Pinto:

Não havia nessas famílias condutas éticas diversas ou formas alternativas de pensar o papel da mulher, mas um ambiente distinto que possibilitou às filhas o acesso ao mundo culto da leitura e da valorização da educação (PINTO, 2003, p. 17).

Assim sendo, Júlia Lopes de Almeida assumiu a função de instruir mulheres e moças da bela época carioca. Pode fazê-lo devido a sua posição social, seus laços familiares e pela percepção do campo intelectual. Para além da discussão, a trajetória de vida aqui exposta teve o intuito de se livrar das armadilhas de uma escrita biográfica. Não obstante, entende-se nesta análise, que há o problema do "eu" e o "outro" na escrita de vida. Talvez, o grande problema enfrentado pelos estudiosos do gênero. Ao falar do personagem, o biógrafo, de certa forma, fala de si mesmo, projeta algo de suas emoções, comunga de seus próprios valores, traz à luz sua subjetividade. Questões que não fugiram na condução deste texto.

\section{Considerações finais}

O presente texto pretendeu discorrer sobre a relação entre Júlia Lopes de Almeida e Filinto de Almeida ao usar como ponto de partida a entrevista concedida a João do Rio. Não só com esta entrevista, mas com uma bibliografia adicional sobre o casal, pôde-se ter uma ideia da relação de companheirismo entre ambos. Vale frisar que o caso de Júlia Lopes de Almeida foi uma exceção à regra. Em fins do século XIX era incomum uma mulher ser influenciada por familiares a dedicar-se às letras.

Por sua vez, a trajetória de Júlia Lopes de Almeida, apesar da guarida familiar, foi permeada por um cenário adverso. A maior parte da intelectualidade do período era formada por homens. O principal agravante, nem todos eram caros à escrita feita por mulheres. Diante

\footnotetext{
Ática ao longo dos anos 1970 e 1980 Seu primeiro livro, A fada que tinha ideias, teve sua primeira edição em 1971 e recebeu o prêmio da FNLIJ - Fundação Nacional do Livro Infantil e Juvenil, como uma das cinco melhores obras infantis brasileiras de 1967-1971. Dentre os outros livros da escritora estão: A margarida Friorenta; Gato que pulava em Sapato; Pinote o Fracote e Janjão, o Fortão; A Aranha, a Dor de Cabeça e Outros Males que assolam o Mundo; Curiosidade Premiada entre outros.
} 
do problema, Júlia Lopes de Almeida, primeiramente, dedicou-se a escrever textos em formato de folhetins, gênero comum à época; livros destinados às outras mulheres, tendo em vista a sua posição social; bem como livros devotados à instrução na infância, que, segundo a ótica do período, eram diletos às mulheres. Além do mais, cumpre lembrar que a escritora foi o baluarte de muitas mulheres, uma vez que foi a presidente de honra da Federação Brasileira pelo Progresso Feminino (FBPF) ${ }^{15}$, instituição liderada por Bertha Lutz e que teve fundamental importância na conquista do sufrágio universal feminino. Em síntese, Júlia Lopes de Almeida, por meio de seu feminismo estratégico, conseguiu se inserir nesta imbricada esfera intelectual a fim de mostrar as suas habilidades no que diz respeito à escrita e deixou sua marca indelével na história da emancipação feminina no Brasil.

\section{Referências primárias}

ALMEIDA, Afonso Lopes de. Mãi. Rio de Janeiro: Typ. do Jornal do Commercio, 1945.

ALMEIDA, Filinto de. Dona Julia. Rio de Janeiro: Typ. do Jornal do Commercio, 1938.

ALMEIDA, Júlia Lopes de Almeida. Livro das noivas. 2.ed. Rio de Janeiro: Francisco Alves \& Cia, 1905.

Livro das donas e donzelas. (coletâneas de crônicas). Rio de Janeiro: Francisco Alves \& Cia, 1906.

GAZETA DE CAMPINAS.

RIO, João do. $O$ momento literário. Rio de Janeiro: Fundação Biblioteca Nacional/Dep. Nacional do Livro, 1994.

\section{Referências subsidiárias}

AVELAR, Alexandre de Sá. A biografia como escrita da História: possibilidades, limites e tensões. Revista de História (UFES), v. 24, p. 157-172, 2010.

BORGES, Vavy Pacheco. O "eu" e o "outro" na relação biográfica: algumas reflexões. In: NAXARA, Márcia; MARSON, Izabel; BREPOHL, Marion (Orgs.). Figurações do outro. Uberlândia: EDUFU, 2009, p.225-238.

BOURDIEU, Pierre. A ilusão biográfica. In: AMADO, Janaína; FERREIRA, Marieta de Moraes Ferreira (Orgs.). Usos e abusos da história oral. Rio de Janeiro: Editora FGV, 1996, p. 183-191.

\footnotetext{
${ }^{15}$ Entidade civil criada no Rio de Janeiro, no ano de 1922, por iniciativa de um grupo de mulheres de classe média, de elevada escolaridade e conhecedoras dos rumos do feminismo na Europa e nos Estados Unidos.
} 
. As regras da arte: gênese e estrutura do campo literário. Trad. de Maria Lúcia Machado. São Paulo: Companhia das Letras. 1996.

. O Poder Simbólico. Rio de Janeiro: Bertrand Brasil, 2003.

A economia das trocas simbólicas. São Paulo: Perspectiva, 2005.

BROCA, Brito. A vida literária no Brasil - 1900. Rio de Janeiro: José Olympio, 1975.

COELHO, Nelly Novaes. Panorama da Literatura Infantil/Juvenil: Das Origens IndoEuropeias ao Brasil Contemporâneo. 4ªed. São Paulo: Ática, 1991.

DE LUCA, Leonora. "A Mensageira”: uma revista de mulheres escritoras na modernização Brasileira.1999. Dissertação (Mestrado em Sociologia). IFCH, UNICAMP, Campinas, 1999.

. Amazonas do pensamento: a gênese de uma intelectualidade feminina no Brasil. 2004. Tese (Doutorado em Ciências Sociais). IFCH, UNICAMP, Campinas, 2004.

DEL PRIORE, Mary. Biografia: quando o indivíduo encontra a História. Topói, v.10, n.19, p. 7-16, jun/dez 2009.

GRIECO, Agripino. "Contistas maiores e menores". In: Evolução da prosa brasileira. São Paulo: José Olympio, 1947. v. 3.

LAJOLO, Marisa; ZILBERMAN, Regina. A formação da leitura no Brasil 2aed., São Paulo: Editora Ática, 1998.

. Literatura infantil brasileira: história \& histórias. 6ª ed. São Paulo: Editora Ática. 1999.

Um Brasil para crianças: para conhecer a literatura infantil brasileira: história, autores e textos. 4.ed. São Paulo: Global, 1993.

LE GOFF, Jacques. A história nova. São Paulo: Martins Fontes, 1990.

MACHADO NETO, Antonio Luís. Estrutura social da república das letras: sociologia da vida intelectual brasileira, 1870-1930. São Paulo, Grijalbo, Universidade de São Paulo, 1973.

MICELI, Sérgio. Intelectuais à brasileira. São Paulo: Companhia das Letras, 2001.

NEEDELL, Jeffrey D. Belle Époque tropical: Sociedade e cultura de elite no Rio de Janeiro na virada do século. São Paulo: Companhia das Letras, 1993.

NOGUEIRA, Maria Alice; NOGUEIRA, Claudio M. Martins. Bourdieu \& a educação. Belo Horizonte: Autêntica, 2004.

PINTO, Celi Regina Jardim. Uma história do feminismo no Brasil. São Paulo: Editora Fundação Perseu Abramo, 2003.

PEREIRA, Lúcia Miguel. Prosa de ficção: de 1870 a 1920. 2.ed. Rio de Janeiro: José Olympio, 
1957.

TELLES, Norma. Orelhas. In: ALMEIDA, Júlia Lopes de. A Falência. Florianópolis: Editora Mulheres e EDUNISC, 2003.

Escritoras, Escritas, Escrituras. In: DEL PRIORE, Mary. (org.) História das mulheres no Brasil. 7.ed. São Paulo: Contexto, 2004.

VERÍSSIMO, José. Letras e literatos. Rio de Janeiro: Leite Ribeiro e Maurillo, 1919.

"Um romance da vida fluminense". In: Estudos de literatura brasileira. Rio de Janeiro: H. Garnier, 1910.

XAVIER, Elódia. A mulher no banco dos réus. In: ALMEIDA, Júlia Lopes de. A Intrusa. Rio de Janeiro: Fundação Biblioteca Nacional, Dep. Nacional do Livro, 1994. p. III.

ARTIGO ENVIADO EM: 29/02/2016 ARTIGO ACEITO PARA PUBLICAÇÃO EM: 01/08/2016 